\title{
Characteristics and Outcomes of Septoplasty in Patients with Paradoxical Nasal Obstruction
}

\author{
Yeon-Jun Yang, Young Hwan Kim, Hong-Geun Kim, \\ Dong-Jun Lee, Ji-Hun Mo, and Young-Jun Chung \\ Department of Otorhinolaryngology-Head and Neck Surgery, Dankook University College of Medicine, Cheonan, Korea
}

\section{역설적 비폐색을 호소하는 환자들의 임상 양상과 비중격성형술의 결과}

양연준 · 김영환 · 김홍근 · 이동준 · 모지훈 · 정영준

단국대학교 의과대학 이비인후-두경부외과학교실

\author{
Received July 3, 2017 \\ Revised August 11, 2017 \\ Accepted August 22, 2017 \\ Address for correspondence \\ Young-Jun Chung, MD \\ Department of Otorhinolaryngology- \\ Head and Neck Surgery, \\ Dankook University \\ College of Medicine, \\ 201 Manghyang-ro, Dongnam-gu, \\ Cheonan 31116, Korea \\ Tel $+82-41-550-3974$ \\ Fax $+82-41-556-1090$ \\ E-mail entdocjung@daum.net
}

Background and Objectives The aim of this study was to evaluate clinical characteristics and outcome of septoplasty in patients complaining of paradoxical nasal obstruction.

Subjects and Method Medical records of 637 patients who underwent septoplasty from 2011 to 2016 were reviewed retrospectively. One hundred sixty-nine patients whose follow up periods were longer than 3 months were included. These patients were categorized into two groups, the experimental group (paradoxical nasal obstruction) and the control group. We analyzed the degree of nasal obstruction, the sino-nasal outcome test (SNOT)-22 score, which is the sino-nasal outcome, and the minimal cross-sectional area in acoustic rhinometry. The effect of concurrent turbinoplasty was also evaluated.

Results Paradoxical nasal obstruction was found in 19 patients (11.2\%). Compared to the control group, the degree of mucosal change (both concave and convex side) had no statistical significance. Although the degree of nasal obstruction and SNOT-22 scores were significantly improved after surgery in both groups $(p<0.05)$, the values for the experimental group were slightly increased at 3 months of surgery after having been improved at one month of surgery. In contrast, those values improved steadily over time in the control group. The tendency of psychologic domain scores was significantly different between the two groups $(p=0.021)$. The results of volume reductive turbinoplasty showed that it maintained the improved symptoms better when performed along with septoplasty.

Conclusion Although septoplasty showed beneficial effects in patients with paradoxical nasal obstruction, the effect of septoplasty decreased over time. Concurrent volume reductive turbinate surgery maintained the effect of septoplasty in paradoxical nasal obstruction.

Korean J Otorhinolaryngol-Head Neck Surg 2018;61(2):91-8

Key Words Acoustic rhinometry · Nasal obstruction · Nasal septum ·

Paradoxical nasal obstruction - Septoplasty.

\begin{abstract}
서 론
비중격 만곡은 만성 비폐색의 가장 흔한 원인이며, 이를

This is an Open Access article distributed under the terms of the Creative Commons Attribution Non-Commercial License (http://creativecommons.org/licenses/by-nc/4.0) which permits unrestricted non-commercial use, distribution, and reproduction in any medium, provided the original work is properly cited.
\end{abstract}

교정하기 위한 비중격성형술은 이비인후과 영역에서 오래전 부터 가장 흔히 시행되고 있는 수술이다. ${ }^{1)}$ 비중격 만곡에 의한 비폐색을 호소하는 환자들은 대부분 비강 용적이 좁은 볼록 면(convex) 쪽에 더 심한 비폐색을 호소하지만, 일부 환자들 은 비강 용적이 넓은 오목면(concave) 쪽의 비폐색을 주소로 내원하는 경우가 있다. 1976년에 Kern과 Arbour'가가 비강이 
상대적으로 넓은 오목면의 비폐색을 호소하는 현상을 '역설 적 비폐색(paradoxical nasal obstruction)이라고 처음으로 명 명하였다.

기존에 역설적 비폐색의 원인 및 기전에 대해 알아보고자 하는 연구가 드물게 있었으나, ${ }^{3)}$ 역설적 비폐색을 호소하는 환자들에서 비중격성형술 후 증상과 삶의 질의 호전 정도가 볼록면의 비폐색을 호소하는 일반적인 비폐색(non-paradoxical) 환자들과 차이점이 있는지를 분석한 연구는 아직까 지 보고된 바가 없다.

따라서, 본 연구에서는 역설적 비폐색을 호소하는 환자들 에서 술 후 호전 정도가 볼록면의 비폐색을 호소하는 일반적 인 환자들과 비교해 어떠한 차이가 있는지를 알아보고, 비강 점막의 수축 정도가 역설적 비폐색 발생에 영향을 미치는지 평가하고자 하였다. 이와 더불어 역설적 비폐색을 호소하는 환자들에서 비중격성형술 시 동시에 시행하는 하비갑개성형 술이 술 후 증상 개선에 미치는 영향을 알아보고자 하였다.

\section{대상 및 방법}

본원에서 2011년 1월부터 2016년 6월까지 비중격성형술을 시행받은 637명 환자의 의무기록을 후향적으로 분석하여 연 구를 진행하였다. 추적관찰 기간이 3 개월 미만이거나 술 전 과 술 후 비내시경 소견과 음향 비강통기도검사, sino-nasal outcome test(SNOT)-22 점수가 기록되어 있지 않은 환자들 은 본 연구에서 제외하였다. 또한 부비동 내시경수술, 비관혈 적 정복술, 구개 편도절제술 등의 다른 수술을 같이 시행받은 환자들과 'S' 모양의 만곡 형태 등 비중격 만곡증의 방향성 을 일측성으로 명확하게 판단할 수 없는 환자들도 본 연구에 서 제외하였다. 외래 방문 시 환자에게 비폐색 증상이 전혀 없는 경우를 0점, 항상 비폐색 증상을 심하게 호소하는 경우 를 10점으로 하는 visual analogue scale을 기록하게 하였으 며, 환자들의 주관적인 비폐색감을 양측 비강에 대해 술 전 과 술 후 각각 측정하였다.

위 조건들을 모두 만족시킨 환자들을 대상으로 병력상 평 소에 뚜렷하게 일측의 코막힘이 심하다는 환자들로 대상을 국한한 다음, 오목면 쪽의 비폐색 점수가 볼록면의 비폐색 점수보다 최소 2점 이상 높은 환자들을 역설적 비폐색군으 로, 볼록면의 비폐색 점수가 오목면의 비폐색 점수보다 2점 이상 높은 환자들을 대조군으로 구분하여 최종적으로 169 명 의 환자를 본 연구에 포함시켰다.

\section{Sino-Nasal Outcome Test-22}

내원 시에 환자들이 작성한 삶의 질 척도인 SNOT-22 점수
를 분석하였다. SNOT-22는 비 영역(rhinologic domain: 재 채기, 콧물, 코막힘, 후각 및 미각 저하, 후비루, 코 풀기), 심리 영역(psychological domain: 좌절감/불안감/흥분감, 슬픔, 당혹감), 귀-안면 영역(ear-facial domain: 이 충만감, 어지럼, 이통, 안면의 압 혹은 통증) 그리고 삶의 질 영역(quality of life domain: 수면장애, 밤중에 기상, 기상 시 피곤함, 지속적 피로감, 생산성 저하, 집중력 저하)으로 총 4가지 영역으로 구 분하여 평가하였다. ${ }^{4)}$

\section{음향 비강통기도검사(Acoustic rhinometry)}

술 전에 시행한 음향 비강통기도검사(acoustic rhinometer, ECCO vision 3.72, Hood Instruments, Pembroke, MA, USA) 를 분석하여 양측 비강의 최소 단면적에 대한 비점막 변화량 (mucosal factor) 값이 역설적 비폐색군과 대조군 간에 차이 가 있는지 분석하였다. 점막 변화량은 비점막 수축제 사용 전 과 후의 최소 단면적 값을 이용해 다음과 같이 계산하였다. ${ }^{3)}$

점막 변화량 $=\frac{\text { 수축 후 최소 단면적-수축 전 최소 단면적 }}{\text { 수축 전 최소 단면적 }} \times 100$

\section{동시에 시행한 하비갑개성형술}

비중격성형술과 동시에 시행한 하비갑개성형술이 술 후 증 상 개선에 미치는 영향을 평가하고, 하비갑개성형술의 종류 에 따라 증상 개선에 차이를 보이는지 분석하였다.

\section{자료 분석 및 처리}

모든 자료는 Statistical Package for the Social Science ver. 20.0(IBM Corp., Armonk, NY, USA)으로 분석하였다. Student t-test, paired t-test 및 repeated measures ANOVA 를 이용하여 유의성을 검증하였고, $p$ 값이 0.05 미만일 때 통 계적 유의성이 있다고 판단하였다.

\section{결 과}

최종적으로 포함된 169명 중 19명(11.2\%)에서 역설적 비폐 색을 호소하였고, 평균 추적관찰 기간은 $7.1 \pm 8.5$ 개월이었다. 역설적 비폐색군과 대조군 간의 평균 나이와 성비 그리고 알 레르기 비염의 동반 비율은 차이가 없었다(Table 1).

\section{술 전 최소 단면적에 대한 점막 변화율(Preoperative mucosal factor of nasal cavity)(Fig. 1)}

볼록면의 최소 단면적에 대한 점막 변화량은 역설적 비폐 색군에서 $36.3 \pm 8.9 \%$ 로 대조군(47.5 $\pm 16.2 \%)$ 에 비해 점막 변 
화율이 더 작았지만, 두 군 간의 유의한 차이는 명확하지 않 았다 $(p=0.079)$. 오목면의 최소 단면적에 대한 점막 변화량은 역설적 비폐색군에서 $16.9 \pm 14.7 \%$ 로 대조군(19.8 $13.4 \%)$ 에 비해 작았으나 유의한 차이는 없었다 $(p=0.769)$.

\section{술 후 두 군 간 최소 단면적의 비교(Table 2)}

술 후 3 개월 시점에 시행한 음향 비강통기도검사에서 오목 면과 볼록면의 최소 단면적은 비점막 수축제의 사용 여부에 관 계없이 두 군간의 통계적인 유의한 차이가 없었다 $(p>0.05)$.

\section{비중격성형술 후 비폐색의 호전 정도(Fig. 2)}

비강 오목면의 비폐색 정도는 역설적 비폐색군에서 술 전

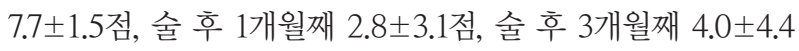
점으로 술 전과 비교해 술 후 1 개월째와 3 개월째 모두 증상

Table 1. Demographic data

\begin{tabular}{lccc}
\hline & $\begin{array}{c}\text { Paradoxical } \\
(\mathrm{n}=19)\end{array}$ & $\begin{array}{c}\text { Control } \\
(\mathrm{n}=19)\end{array}$ & p-value \\
\hline Mean age $(\mathrm{yr})$ & $29.9 \pm 15.3$ & $32.5 \pm 13.3$ & 0.503 \\
M:F & $14: 5$ & $122: 28$ & 0.537 \\
Allergic rhinitis & 12 & 96 & 0.799 \\
\hline
\end{tabular}

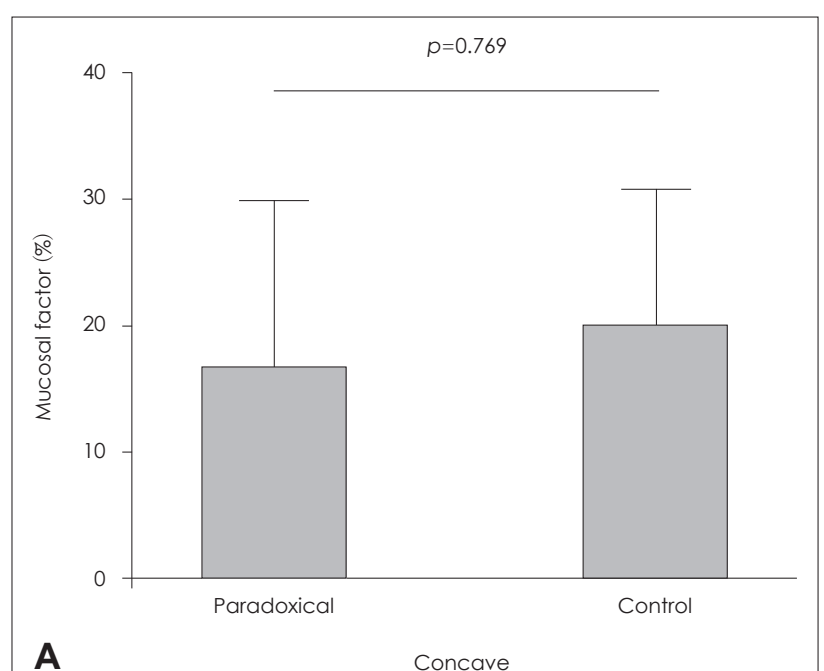

이 유의하게 호전되었다 $(p<0.001, p=0.019$, respectively)(Fig.

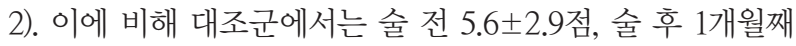
$3.3 \pm 2.5$ 점, 술 후 3 개월째 $2.1 \pm 2.0$ 점으로 역설적 비폐색군과 는 달리 시간이 경과함에 따라 유의하게 증상의 호전이 지속 되는 양상이었다 $(p=0.031, p=0.008$, respectively). 비강 볼록 면에서는 역설적 비폐색군에서 술 전 3.8⒊2점에서 술 후 1 개월째 $1.4 \pm 2.3$ 점으로 증상이 호전되며 $(p=0.008)$, 술 후 3 개 월째는 2.4 2 .2점으로 점수의 상승을 보이나 1 개월째와 비 교하여 통계적으로 유의한 차이는 없었다. 대조군에서는 술

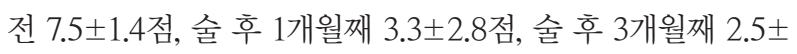
2.9점으로 시간의 경과에 따라 유의한 증상의 호전이 지속됨 을 보였다 $(p<0.001$, both $)$.

삶의 질 척도의 변화(Change of SNOT-22 score)(Fig. 3) 삶의 질 척도의 총 합산 점수는 역설적 비폐색군에서는 술

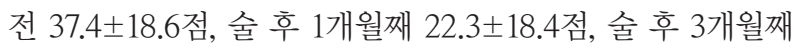
$24.7 \pm 25.6$ 점으로, 술 전에 비해 술 후 삶의 질이 호전되었고 $(p<0.001, p=0.005)$, 술 후 3 개월째는 유의성은 없었지만 술 후 1 개월째와 비교해 상승하는 경향을 보였다(Fig. $3 \mathrm{~A}$ ). 대조 군에서는 술 전과 비교해 술 후 1 개월과 3 개월째 모두 의미 있

Fig. 1. Degree of mucosal change analyzed by acoustic rhinometry on concave and convex side in the paradoxical and control groups prior to surgery. Degree of mucosal change of the paradoxical group is smaller than that of the control group in both concave $(A)$ and convex (B) side. However, significant differences were not found between two groups.

Table 2. Comparison of the MCA at postoperative 3 months

\begin{tabular}{lccc}
\hline & Paradoxical $(n=19)$ & Control $(n=19)$ & $p$-value \\
\hline Concave side MCA, baseline & $0.59 \pm 0.18$ & $0.58 \pm 0.19$ & 0.371 \\
Concave side MCA, decongested & $0.67 \pm 0.22$ & $0.66 \pm 0.18$ & 0.527 \\
Convex side MCA, baseline & $0.53 \pm 0.19$ & $0.51 \pm 0.16$ & 0.204 \\
Convex side MCA, decongested & $0.66 \pm 0.21$ & $0.63 \pm 0.18$ & 0.137 \\
\hline
\end{tabular}

MCA: minimal cross-sectional area

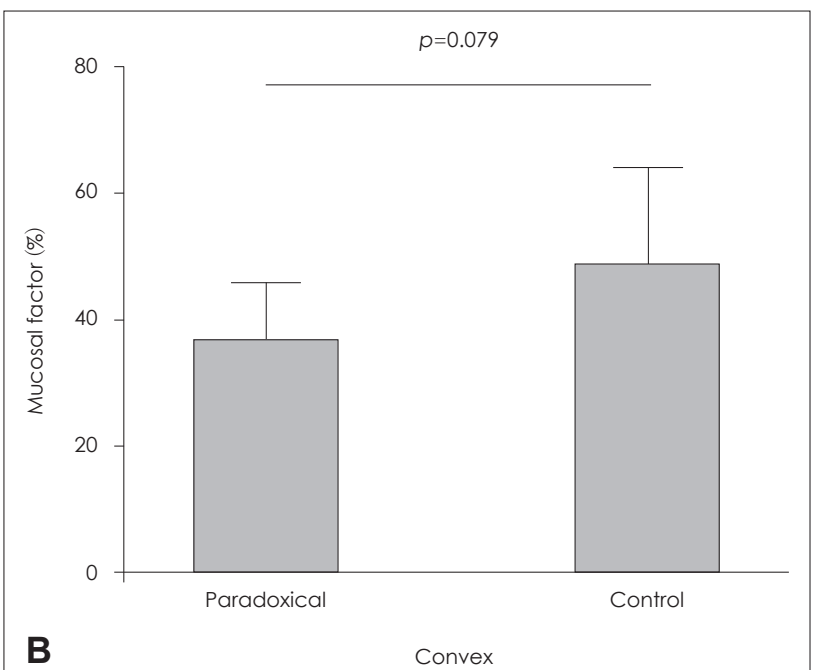




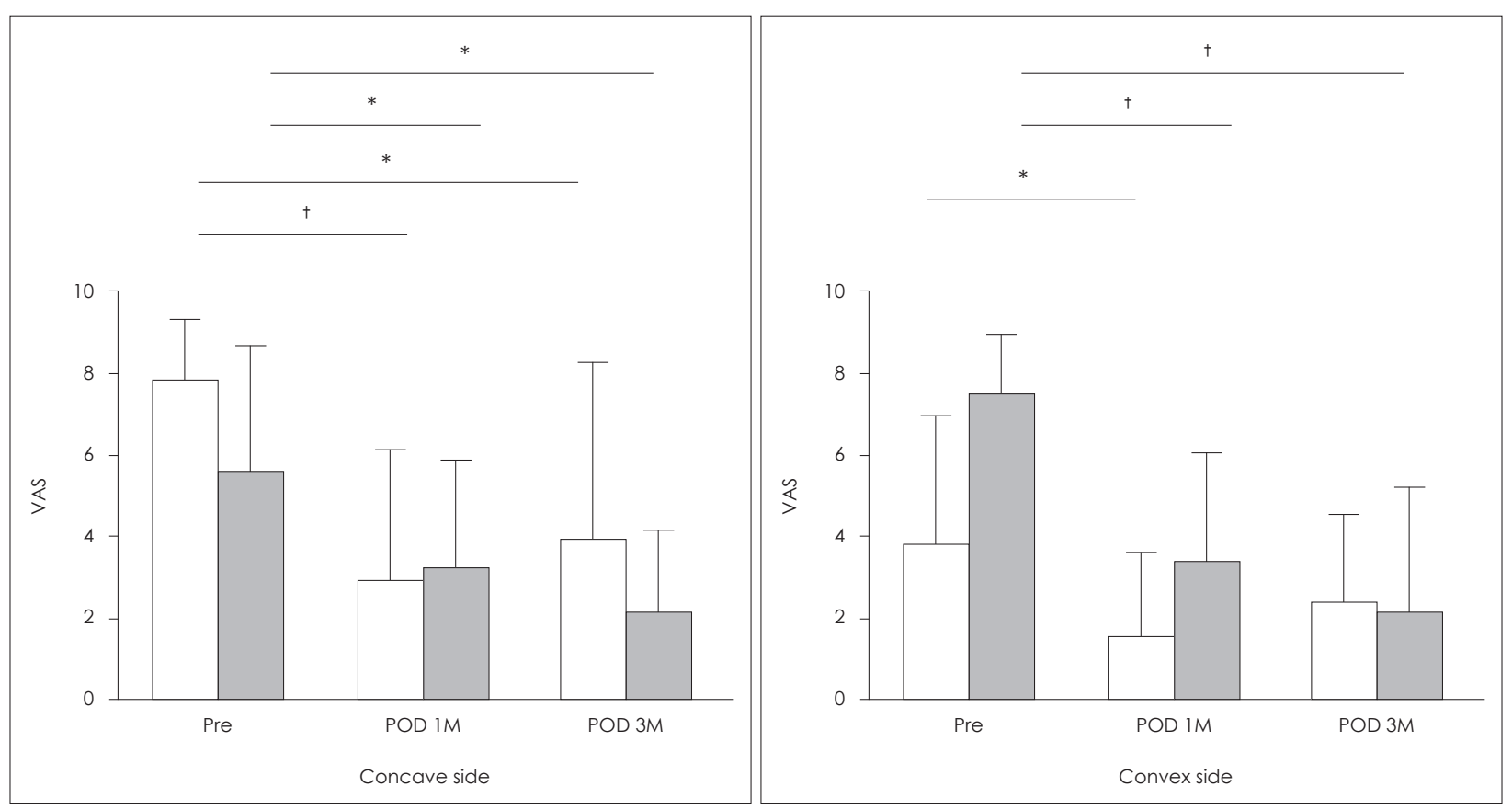

Fig. 2. Change of nasal obstruction scores of the concave and convex nasal cavity. In paradoxical group, the degree of nasal obstruction scores of the both nasal cavity in 1 month after surgery were decreased compared to those in pre-operation. However, those in 3 months after surgery were slightly increased compared to those in 1 month. On the other hand, those values in the control group gradually decreased significantly over time after surgery, both concave and convex side of the nasal cavity. Gray box represents the paradoxical nasal obstruction group and white box represents the control group, respectively. ${ }^{*} p<0.05,{ }^{\dagger} p<0.001$. VAS: visual analogue scale, POD: post-operative day, M: month.

는 호전을 보였지만 $(p<0.001)$, 역설적 비폐색군과는 달리 술 후 3개월째의 점수가 술 후 1개월째 점수보다 유의하게 낮아 시간의 경과에 따라 점차 개선되는 양상이었다(Fig. 3A).

비영역에서도 역설적 비폐색군에서 술 전 $15.8 \pm 6.3$ 점, 술

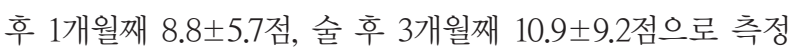
되어, 술 전에 비해 술 후 각 시점에서 점수의 개선이 관찰되었 다 $(p<0.001, p=0.008$, respectively)(Fig. 3B). 하지만 앞서 언 급한 비폐색 혹은 SNOT-22 총 합산 점수와 같이 술 후 3 개 월째 다시 상승하는 경향을 보였고, 이런 경향은 삶의 질 영역 에서도 같은 양상으로 관찰되었다(Fig. $3 \mathrm{C}$ ). 이와 비교해 대 조군에서는 비영역, 삶의 질 영역 모두에서 시간의 경과에 따라 점수가 개선되는 양상으로 관찰되었다 $(p<0.001)$.

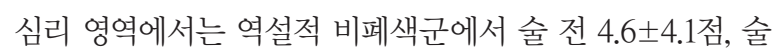
후 1 개월째는 $2.3 \pm 3.5$ 점으로 점수가 의미 있게 호전되었으나 ( $p=0.006)$, 술 후 3 개월째는 $3.7 \pm 5.8$ 점으로 술 후 1 개월째보 다 유의하게 점수가 악화되었다 $(p=0.009)$ (Fig. $3 \mathrm{E}$ ). 대조군에

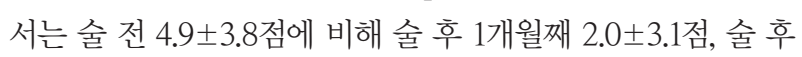
3 개월째 $1.5 \pm 3.0$ 점으로 술 후 지속적인 점수의 개선을 보였 다 $(p<0.001$, both $)$.

두 군 사이에 시간 경과에 따른 삶의 질 척도 점수가 변화 하는 양상이 차이를 보이는지 알아보고자 추가적인 분석에 서 심리 영역에서만 두 군 간의 유의한 차이가 관찰되었고
( $p=0.021$, repeated measures ANOVA), 나머지 영역 및 증 상 점수에서는 유의한 차이를 보이지 않았다.

\section{역설적 비폐색군에서 하비갑개성형술의 역할}

역설적 비폐색군 19 명 중 18 명과 대조군 150 명 중 128명에 서 비중격성형술과 함께 하비갑개성형술을 동시에 시행하였 다. 역설적 비폐색군에서 비강 오목면에 하비갑개 외골절술 만 시행한 경우 비폐색 점수는 술 전 8.0 \pm 1.6 점, 술 후 1개월 째 2.2 \pm 3.4 점으로 유의하게 개선되었으나 $(p<0.001)$, 술 후 3 개월째는 4.6 \pm 4.8점으로 술 후 1 개월째에 비해 비폐색 정도 가 유의하게 상승하였다( $p=0.012)$ (Fig. $4 \mathrm{~A})$. 이에 반해, 코블 레이터를 이용한 점막하축소술이나 하비갑개 점막하절제술 을 함께 시행한 환자들에서는 술 전 7.6 \pm 1.4 점에 비해, 술 후 1 개월째 $3.2 \pm 2.8$ 점, 술 후 3 개월째 $3.6 \pm 3.8$ 점으로 시간이 경과 해도 증상 개선이 유지되는 양상으로 관찰되었다 $(p<0.001$, $p=0.008$, respectively). 대조군에서 비강 오목면에 하비갑개 외골절술만 시행한 경우 비폐색 점수는 술 전 $5.4 \pm 2.8$ 점, 술 후 1 개월째 $3.7 \pm 2.5$ 점으로 유의하게 호전되었으며, 술 후 3 개 월째는 3.1 3.0 점으로 지속적인 개선을 보였다 $(p=0.034, p=$ 0.021, respectively)(Fig. 5A), 코블레이터를 이용한 점막하 축소술이나 하비갑개 점막하절제술을 함께 시행한 대조군 에서도 마찬가지로 술 전 $5.2 \pm 3.1$, 술 후 1 개월째 $3.4 \pm 2.8$, 그 

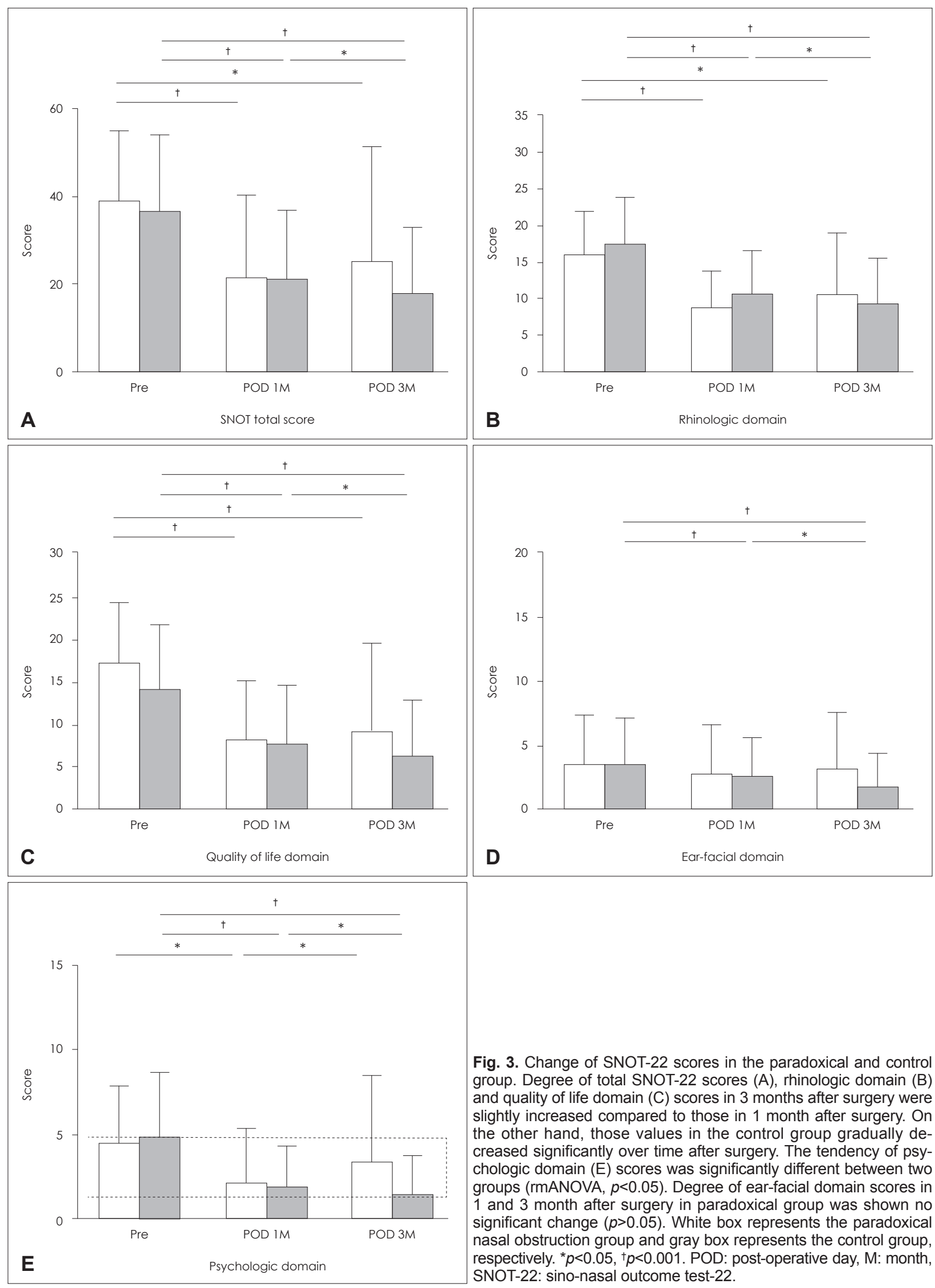

Fig. 3. Change of SNOT-22 scores in the paradoxical and control group. Degree of total SNOT-22 scores $(A)$, rhinologic domain $(B)$ and quality of life domain $(C)$ scores in 3 months after surgery were slightly increased compared to those in 1 month after surgery. On the other hand, those values in the control group gradually decreased significantly over time after surgery. The tendency of psychologic domain $(\mathrm{E})$ scores was significantly different between two groups (rmANOVA, $p<0.05$ ). Degree of ear-facial domain scores in 1 and 3 month after surgery in paradoxical group was shown no significant change $(p>0.05)$. White box represents the paradoxical nasal obstruction group and gray box represents the control group, respectively. ${ }^{*} p<0.05,{ }^{\dagger} p<0.001$. POD: post-operative day, M: month, SNOT-22: sino-nasal outcome test-22. 


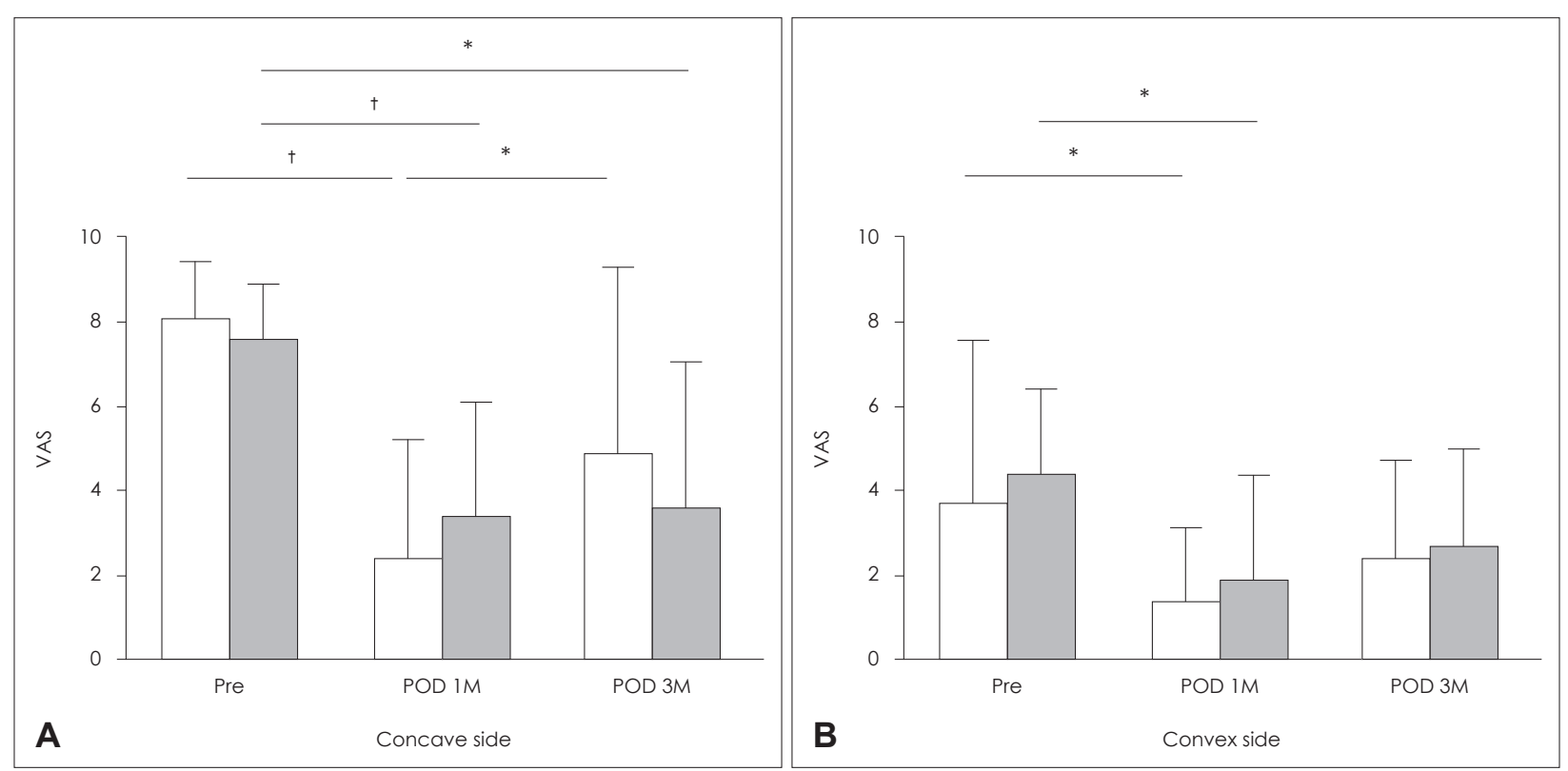

Fig. 4. Role of concurrent turbinoplasty in patients with paradoxical nasal obstruction. Effect of two different turbinoplasty techniques (ITOF vs. TwITOF) was compared using visual analogue scale reflecting degree of nasal obstruction (A and B). After septoplasty with ITOF technique, degree of nasal obstruction was aggravated at postoperative 3 months showing statistical difference between 1 month and 3 months $(A, p=0.012)$. In contrast, after septoplasty with TwITOF technique, symptom scores did not differ between two time points, suggesting maintenance of the improved symptoms. Gray box represents septoplasty with ITOF technique and white box represents septoplasty with TwITOF technique. ${ }^{*} p<0.05,{ }^{\dagger} p<0.001$. ITOF: inferior turbinate out-fracture, TwITOF: out-fracture technique with either coblator-assisted turbinoplasty or submucosal resection.
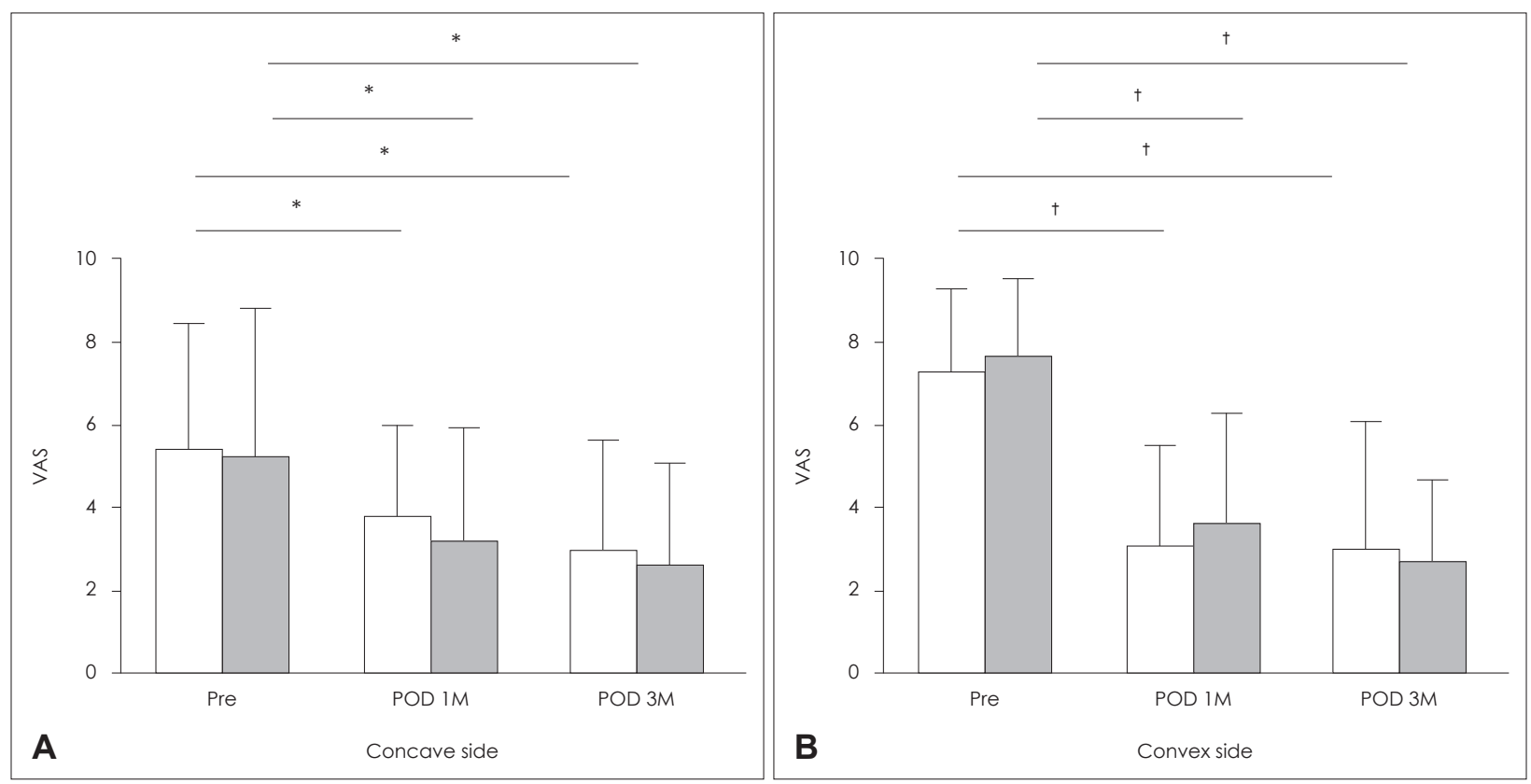

Fig. 5. Role of concurrent turbinoplasty in control group. Effect of two different turbinoplasty techniques (ITOF vs. TwITOF) was compared using visual analogue scale reflecting degree of nasal obstruction ( $A$ and $B$ ). Regardless of the techenique of the turbinoplasty, degree of nasal obstruction was improved at postoperative 1 and 3 months $(A, p<0.05)$. Gray box represents septoplasty with ITOF technique and white box represents septoplasty with TwITOF technique. ${ }^{*} p<0.05,{ }^{\dagger} p<0.001$. ITOF: inferior turbinate out-fracture, TwITOF: out-fracture technique with either coblator-assisted turbinoplasty or submucosal resection. 
은 연구를 통해 입증되었지만,5) 역설적 비폐색을 호소하는 환자들에서 술 후 호전 정도가 볼록면의 비폐색을 호소하는 일반적인 환자들과 어떤 차이점이 있는지를 비교한 연구는 아직까지 보고된 바 없다. 본 연구의 임상적 의미는 역설적 비폐색을 호소하는 환자에서 비중격성형술 후 일반적인 볼 록면의 비폐색을 호소하는 환자들과는 다른 임상적 경과 패 턴을 보인다는 점과 비갑개 수술을 시행할 때 비갑개의 부피 를 줄이는 수술을 함께 시행하여 주는 것이 단순한 외골절 술만 시행하는 경우보다 증상 개선 지속에 더 효과적이라는 임상적 근거를 제시한 점이다.

본 연구에서는 추적관찰 기간, 타 수술 병행 여부, 비중격의 만곡의 적절성, 설문 및 음향 비강통기도 시행 여부 등을 모 두 고려하여 환자군을 설정하였고, 최종적으로 포함된 169명 의 환자 중 19명(11.2\%)에서 역설적 비폐색을 호소하여 선행 연구(3\%)에 비해 높은 빈도를 보였으나, 선행연구와 같은 방 법으로 유병률을 분석한 결과에서는 초기 연구 대상이었던 637명 중 27명(4.2\%)에서 역설적 비폐색을 호소하여 기존 보 고와 비슷한 비율을 보였다. ${ }^{3)}$ 따라서, 비중격 만곡증으로 인 한 비폐색을 호소하는 환자들 중 역설적 비폐색감을 호소하 는 환자들의 비율은 3 5\% 정도로 추정된다.

역설적 비폐색은 Kern과 Arbour ${ }^{2}$ 에 의해 처음으로 명명 되었는데, 이를 비주기 현상과 연관 지어 설명하였다. ${ }^{6}$ 비강 의 볼록면은 비중격 만곡으로 인해 어느 정도의 비폐색이 항 상 유지되어 환자 스스로가 볼록면 비강이 막힌다는 느낌을 무의식 중에 잊어버리게 되지만, 비강의 오목면은 비주기로 인해 비갑개 크기가 변화되어 코가 막혔다가 개방되는 증상 에 대해 환자 스스로가 인지하기 때문에 역설적 비폐색이 발 생한다고 주장하였다. ${ }^{2)}$ 이후 다른 연구에서도 역설적 비폐색 을 호소하는 환자들에서 비강 볼록면의 비점막 변화량이 적 어 상대적으로 일정한 양의 비호흡이 지속적으로 이루어져 환자 스스로가 볼록면 비강의 비폐색은 인지하지 못하는 반 면, 비강이 상대적으로 넓은 오목면은 비호흡의 저항성이 비 주기에 따라 크게 변화하기 때문에 코가 막히는 증상을 의 식하게 된다는 것으로 설명하였다. ${ }^{3)}$ 술 전에 시행한 음향 비 강통기도검사로 점막의 변화량을 평가한 본 연구에서도 통 계적 유의성은 명확하진 않았으나 비강 볼록면의 점막 변화 량이 역설적 비폐색군에서 대조군에 비해 적은 경향을 보여 기존 연구에서 제시한 바와 같이 볼록면의 비폐색은 인지하 지 못하는 반면, 오목면에서는 비주기에 따라 비폐색을 인지 하게 됨으로써 역설적 비폐색이 발생하는 것으로 판단된다.

비중격 만곡 형태를 분류하는 방법은 여러 연구자들에 의 해 다양하게 제안되고 있는데, 대부분의 공통적 부분은 'C' 모양의 비중격 만곡과 'S' 모양의 비중격 만곡이 정방향 혹은
역방향으로 상하방축(cephalocaudal) 혹은 전후방축(anteroposterior)을 향해 뻗어 나간다는 것을 고려했다는 점이 다.) 본 연구에서는 비중격의 만곡을 내시경 소견으로 비강 의 오목면과 볼록면을 구분하는 것이 중요한 요소였다. 실제 로 본 연구에서 비중격 교정술을 받은 환자들은 다양한 형 태의 비중격 만곡을 보였기 때문에, 비중격 만곡의 방향을 정확히 판단할 수 없는 'S' 모양의 만곡을 가진 환자들을 연 구에서 제외시켜 볼록면과 오목면의 구분을 단순화시킴으로 써 연구의 오류를 줄이고자 하였다. 결과적으로 정방향 혹은 역방향의 'C' 모양이 상하방축 혹은 전후방축으로 보이며 일 측성의 비중격 만곡을 확실히 판단할 수 있는 환자들만을 본 연구에 포함시켜 역설적 비폐색 환자들의 임상 양상을 분 석하였기 때문에 모든 비중격 만곡 형태에 대해 분석하지 못 한 점은 본 연구의 제한점이라고 생각된다.

본 연구에서는 역설적 비폐색군과 대조군 모두에서 수술 적 치료가 증상의 개선에 효과가 있음을 확인하였으나, 역설 적 비폐색군에서는 모든 SNOT-22 영역과 비폐색 점수가 수 술 후 1 개월에 비해 수술 후 3 개월째 다시 상승하는 경향을 보인 반면, 대조군에서는 모든 영역과 비폐색 점수가 수술 후 1 개월에 비해 수술 후 3 개월째에 더 개선된 양상으로 관찰되 었다. 두 군 사이의 점수 변화 양상은 심리 영역에서만 통계 적으로 유의한 차이를 보였는데, 모든 영역 및 증상 점수의 변화 양상이 심리 영역과 비슷한 경향을 보인 것을 고려해 볼 때 심리적인 면이 역설적 비폐색군의 술 후 경과에 영향을 미치는 것으로 판단된다. 또한, 3 개월 이상의 외래 추적관찰 을 시행한다면 보다 정확하고 장기적인 증상 및 점수의 변화 양상을 파악할 수 있을 것이나, 증상이 호전된 환자들이 장기 추적을 선호하지 않는 등의 임상 영역에서의 현실적인 어려움 이 존재하기에 3 개월을 마지막 추적관찰 기간으로 설정하였다. 일반적인 비폐색을 호소하는 환자에게 비중격교정술 및 하비갑개성형술을 시행하는 것이 증상 호전에 도움이 된다는 것은 선행 연구를 통해 이미 밝혀져 왔다. ${ }^{8,9}$ 본 연구는 역설 적 비폐색을 호소하는 환자에서 보상성 비대를 보이는 비강 오목면의 하비갑개와 보상성 비대 없이 상대적으로 크기가 작은 볼록면의 하비갑개가 어떠한 하비갑개성형술에 더욱 효과적일지를 알아보고자 하였다. 가장 좋은 방법은 역설적 비폐색군에서 하비갑개성형술을 시행한 환자들과 시행하지 않은 환자들을 비교하는 방법이 있겠으나, 본 연구에 포함된 역설적 비폐색을 호소하는 환자들 중 하비갑개성형술을 시 행하지 않은 환자는 1 명밖에 되지 않아 통계적 수치를 얻기 에 어려움이 있었다. 따라서 대조군과의 비교를 통해 비폐색 증상의 변화를 확인하였으며, 본 연구의 결과로는 비중격성형 술과 함께 오목면의 하비갑개성형술을 시행하는 경우에 하비 
갑개 점막하절제술이나 코블레이터를 이용한 방법을 병용하 는 술식이 하비갑개 외골절술만 단독으로 시행하는 것보다 역 설적 비폐색군에서 술 후 개선된 증상을 지속시키는 데 더 효 과적이었다. 따라서 역설적 비폐색을 호소하는 환자의 수술 시에는 이런 점을 고려해 오목면에 대해서는 하비갑개수술 을 병행할 때 부피를 줄여주는 수술을 함께 시행하는 것이 환자의 수술 만족도를 높이는 데 도움이 될 것으로 판단된다. 비강 볼록면에서는 대부분의 환자에서 하비갑개 외골절술만 을 시행하였는데, 이는 오목면의 하비갑개와 달리 보상성 비 대가 없는 볼록면의 하비갑개 부피가 상대적으로 작기 때문 에 수술을 시행한 술자의 판단에 따라 부피를 줄이는 술식 을 시행하지 않았기 때문일 것으로 추측된다.

본 연구를 진행하면서 생겼던 의문 중 하나는 역설적 비폐 색을 호소하는 환자에게 비중격 교정술 없이 비강 오목면의 하비갑개성형술만으로 역설적 비폐색을 호전시킬 수 있는지 에 대한 부분이다. 선행연구의 결과에선 역설적 비폐색을 일 으키는 원인이 비강 오목면에 있는 것이 아니라 비강 볼록면 의 점막 변화량이 적어서 발생한다고 언급하였다. 이것은 역 설적 비폐색의 원인이 비강 볼록면에 존재한다는 의미가 되 고, 따라서 비강 오목면에 단독으로 시행하는 하비갑개성형 술은 오목면의 비폐색 증상에 대해 적절한 효과를 보지 못 할 가능성이 높을 것으로 판단된다. 본 연구의 결과로 미루
어 볼 때, 비중격성형술과 더불어 적절한 하비갑개성형술을 병행하는 것이 증상 개선에 도움이 될 것으로 사료된다.

\section{REFERENCES}

1) Tompos T, Garai T, Zemplén B, Gerlinger I. Sensation of nasal patency compared to rhinomanometric results after septoplasty. Eur Arch Otorhinolaryngol 2010;267(12):1887-91.

2) Kern EB, Arbour P. The phenomenon of paradoxical nasal obstruction. Arch Otolaryngol 1976;102(11):669-71.

3) Kim HY, Dhong HJ, Hong SD, Lee HJ, Cho HJ, Chung SK. Paradoxical nasal obstruction: analysis of characteristics using acoustic rhinometry. Am J Rhinol 2007;21(4):408-11.

4) Kennedy JL, Hubbard MA, Huyett P, Patrie JT, Borish L, Payne SC. Sino-nasal outcome test (SNOT-22): a predictor of postsurgical improvement in patients with chronic sinusitis. Ann Allergy Asthma Immunol 2013;111(4):246-51.e2.

5) Bugten V, Nilsen AH, Thorstensen WM, Moxness MH, Amundsen MF, Nordgård S. Quality of life and symptoms before and after nasal septoplasty compared with healthy individuals. BMC Ear Nose Throat Disord 2016;16:13.

6) Heetderks DR. Observations on the reaction of normal nasal mucous membrane. Am J Med Sci 1927;174(2):231-44.

7) Teixeira J, Certal V, Chang ET, Camacho M. Nasal septal deviations: a systematic review of classification systems. Plast Surg Int 2016;2016: 7089123.

8) Lee TH, Kim BY, Kim DY. Effectiveness of the turbinoplasty in the patient with deviated septum of nose. Korean J Otolaryngol-Head Neck Surg 2005;48(3):326-31.

9) Kim SW, Park HJ, Jun BC, Ahn KJ, Lee SK, Kim SW, et al. Nasal septal deviation and compensated inferior turbinate hypertrophy. Korean J Otolaryngol-Head Neck Surg 2005;48(1):46-50. 